\title{
Patterns of $\mathrm{p} 21^{\text {wafl/cip } 1}$ expression in non-papillomatous nasal mucosa, endophytic sinonasal papillomas, and associated carcinomas
}

\author{
M J Schwerer, A Sailer, K Kraft, K Baczako, H Maier
}

\begin{abstract}
Aims-To clarify p $21^{\text {wafl/cip1 }}$ expression in sinonasal lesions.

Methods-Archived surgical specimens from 38 patients were investigated by means of immunohistochemistry. p21 $1^{\text {wafl/cip1 }}$ staining was evaluated in the different layers of the epithelium. In addition, human papillomavirus (HPV) infection and p53 protein overexpression were assessed and correlated with $p 21^{\text {wafl/cip1 }}$ expression.
\end{abstract}

Results-p $21^{\text {wafl/cip1 }}$ staining was negative in non-papillomatous nasal mucosa. HPV infection and p53 protein overexpression were not seen. Sixteen of 20 inverted papillomas showed p21 $1^{\text {wafl/cip1 }}$ expression. HPV infection was found in 16 cases and p53 protein overexpression was present in 13 specimens. Expression of p21 $1^{\text {wafl/cip1 }}$ was restricted to surface cells in five cases, but involved basal/parabasal cells in 11 specimens. Immunoreactivity for $\mathrm{p} 21^{\text {wafl/cip1 }}$ in basal/parabasal cells colocalised with p53 protein overexpression. Enhanced expression rates for $\mathrm{p} 21^{\text {wafl/cip1 }}$ were seen in transitional and squamous epithelium compared with columnar epithelium. p21 wafl/cip1 expression involved only surface cells in cylindrical cell papillomas. HPV infection and p53 protein overexpression were detected in all specimens. One of five squamous cell carcinomas showed p2 $1^{\text {wafl/cip1 }}$ expression. HPV infection was seen in two cases, and all carcinomas showed p53 protein overexpression.

Pathology, Military

Hospital Ulm, D-89081

Ulm/Donau, Germany

M J Schwerer

A Sailer

K Kraft

Institute of Pathology, Eberhard-Finckh-Straße 47, D-89075

Ulm/Donau, Germany

K Baczako

Department of

Otorhinolaryngology,

Head and Neck

Surgery, Military

Hospital Ulm

H Maier

Correspondence to:

Professor Baczako

karl.baczako@

medizin.uni-ulm.de

Accepted for publication 1 May 2001

Conclusions-Expression of $\mathrm{p}^{2} 1^{\text {wafl/cip1 }}$ is associated with terminal differentiation in surface cells in inverted papillomas and cylindrical cell papillomas, but not in non-papillomatous nasal mucosa. Overexpression of $\mathrm{p} 53$ protein colocalises with p21 wafl/cip1 expression in basal/parabasal cells in inverted papillomas but not in cylindrical cell papillomas. Expression of p2 $1^{\text {wafl/cip1 }}$ in squamous cell carcinomas involves a subset of tumours with p53 protein overexpression.

(F Clin Pathol 2001;54:871-876)

Keywords: $\mathrm{p} 21^{\text {wafl/cip } 1}$; nasal mucosa; sinonasal papillomas; squamous cell carcinomas

The waf1/cip1 (wild-type p53 associated fragment/cyclin dependent kinase (cdk) interacting protein) gene is localised on chromosome band $6 \mathrm{p} 21.2$ in the human genome. ${ }^{12}$ It encodes a $21 \mathrm{kDa}$ protein, $\mathrm{p} 21^{\text {wafl/cip1 }}$, which in normal cells exists in quarternary complexes with cyclins, cdks, and proliferating cell nuclear antigen. ${ }^{3-5}$ Complexing of $\mathrm{p} 21^{\text {wafl/cip1 }}$ inhibits the activity of cdks and thereby controls the $G_{1}$ to $S$ phase transition of the cell cycle. ${ }^{3-5}$ The induction of $\mathrm{p} 21^{\text {wafl/cip } 1}$ is associated with terminal differentiation, senescence, and apoptosis in several tissues. ${ }^{236}$ Furthermore, p2 $1^{\text {wafl/cip1 }}$ acts as a downstream mediator of wild-type p53 protein, suppressing DNA replication under genomic stress. ${ }^{1-4} 7$ Although p2 $1^{\text {wafl/cip1 }}$ functions as a putative tumour suppressor, mutations of the wafl/cip1 gene have been detected only rarely in human malignancies. ${ }^{89}$

Recently, p2 $1^{\text {wafl/cip1 }}$ expression has been demonstrated in several head and neck malignancies - for example, oral squamous cell carcinomas and their precursors. ${ }^{10}{ }^{11}$ However, $\mathrm{p} 21^{\text {wafl/cip } 1}$ expression has not yet been investigated in the nasal mucosa and in sinonasal lesions. Endophytic sinonasal papillomas, comprising inverted papillomas and cylindrical cell papillomas according to the World Health Organisation classification, show malignant progression in up to $25 \%$ of cases. $^{12-14}$ Squamous cell carcinomas associated with endophytic sinonasal papillomas develop either synchronous or metachronous to the original papilloma. ${ }^{13}{ }^{14}$ However, sinonasal squamous cell carcinomas developing independently from endophytic sinonasal papillomas are a rare type of tumour. ${ }^{13-15}$

We aimed to clarify the patterns of $\mathrm{p} 21^{\text {waf1/cip } 1}$ expression in nasal mucosa, endophytic sinonasal papillomas, and their associated squamous cell carcinomas.

\section{Methods}

TISSUE SELECTION AND STANDARD HISTOLOGY A highly selective cohort of 38 patients (30 men, eight women; age range, 17-76 years; median, 49) was investigated. Archived surgical specimens were retrieved from the files of the department of pathology, Military Hospital exact clinical documentation of the origin and extension of the lesions was used exclusively. Furthermore, only specimens with an adequate amount of lesional material were investigated. Cases showing insufficient fixation, necrosis, haemorrhage, and/or atrophy were excluded. Histological examination for adequacy of lesional tissue and classification of specimens was carried out by two independent observers using haematoxylin and eosin stained slides. Differences between their individual reports were resolved by re-examination and consensus. Non-papillomatous nasal mucosa was Ulm, Ulm/Donau, Germany. Material with 
Table 1 Expression of $p 21^{\text {wafilicit } 1}$ in 20 inverted papillomas

\begin{tabular}{|c|c|c|c|c|c|c|}
\hline & \multicolumn{2}{|c|}{ Basal/parabasal cells } & \multicolumn{2}{|c|}{ Median cell layer } & \multicolumn{2}{|l|}{ Surface cells } \\
\hline & p21 negative & p21 positive & p21 negative & p21 positive & p21 negative & p21 positive \\
\hline \multicolumn{7}{|c|}{ Columnar epithelium } \\
\hline p53 negative & 5 & 0 & 5 & 0 & 1 & 4 \\
\hline p53 positive & 3 & 3 & 6 & 0 & 0 & 6 \\
\hline \multicolumn{7}{|c|}{ Transitional epithelium } \\
\hline p53 negative & 7 & 0 & 7 & 0 & 7 & 0 \\
\hline p53 positive & 3 & 9 & 11 & 1 & 5 & 7 \\
\hline \multicolumn{7}{|c|}{ Squamous epithelium } \\
\hline p53 negative & 5 & 0 & 5 & 0 & 5 & 0 \\
\hline p53 positive & 2 & 9 & 11 & 0 & 7 & 4 \\
\hline
\end{tabular}

Columnar epithelium was present in 11 cases, transitional epithelium in 20 cases, and squamous differentiation in 16 specimens.

studied in seven cases with either normal nasal mucosa or minimal chronic inflammation. Specimens with more than minimal chronic inflammation, active inflammation, dysplasia, or carcinoma were excluded. Twenty six endophytic sinonasal papillomas were studied, comprising 20 inverted papillomas and six cylindrical cell papillomas. Specimens with dysplasia or associated malignancies were excluded from this group. Five squamous cell carcinomas associated with endophytic sinonasal papillomas were investigated.

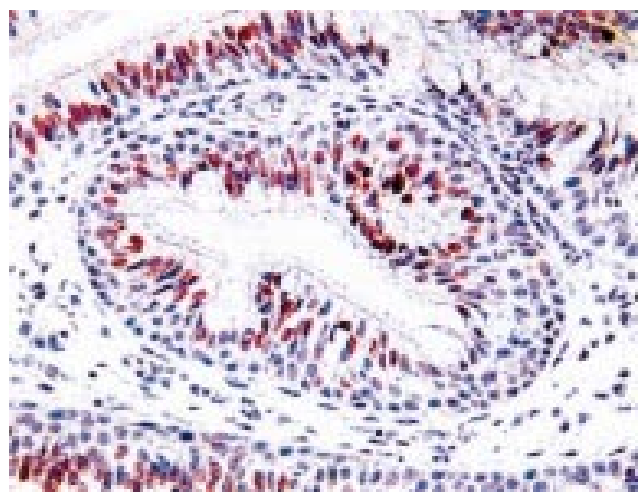

Figure 1 Columnar epithelium in the invaginating portion of an inverted papilloma from a 45 year old man. Positive staining for $p 21^{\text {waflicipl } 1}$ is restricted to surface cells. Negative staining for $p 21^{\text {vaflicipl }}$ in basal/parabasal cells, although human papillomavirus infection and $p 53$ protein overexpression were present in this specimen.

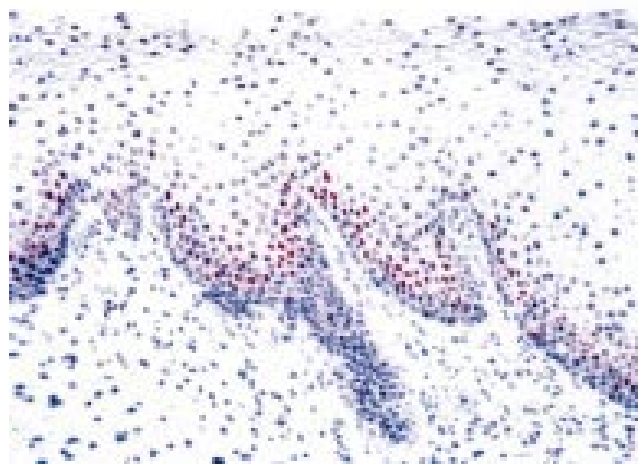

Figure 2 Squamous epithelium in an inverted papilloma (same specimen as shown in fig 1). Note abundant

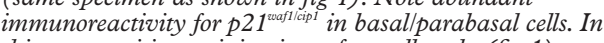
this case, positive staining in surface cells only (fig 1 ) together with positive staining in basal/parabasal cells only (fig 4) were found in different regions within the same specimen.
IMMUNOHISTOCHEMISTRY

Additional $5 \mu \mathrm{m}$ paraffin wax embedded sections were prepared and immunohistochemistry was carried out using the streptavidinbiotin-peroxidase technique, as reported previously. ${ }^{16}$ For all antibodies, a microwave based antigen retrieval protocol was used for a total of 30 minutes in citrate buffer $(\mathrm{pH} 6.0){ }^{17}$

The NCL-Waf 1 antibody (Novocastra, Newcastle upon Tyne, UK) was used for $\mathrm{p} 21^{\text {wafl/cip1 }}$ staining, at a dilution of $1 / 20$. Gastric body mucosa samples provided positive controls. Distinct nuclear staining was found in foveolar cells on the gastric tips, in addition to terminally differentiated cells in the glands. Furthermore, reproducible strong staining in vascular smooth muscle cells was seen in all specimens, which served as an internal positive

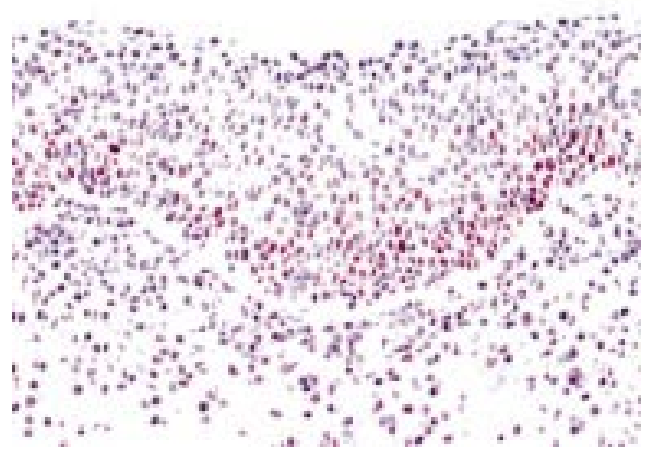

Figure 3 Transitional epithelium in an inverted papilloma from a 25 year old man. Abundant immunoreactivity for p53 protein is present in the lower half of the epithelium. Human papillomavirus infection was demonstrated in this specimen.

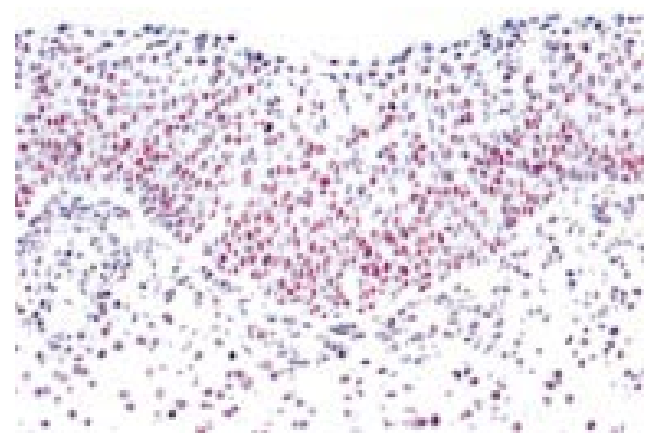

Figure 4 Immunoreactivity for $p 21^{\text {vafllipip } 1}$ in a serial slide from the same lesion shown in fig 3. Note colocalisation of positive staining results for $p 53$ protein and $p 21^{\text {wafflicip } 1}$ between figs 2 and 3 . 
Table 2 Expression of $p 21^{\text {waflicipt }}$ in cylindrical cell papillomas $(n=6)$

\begin{tabular}{|c|c|c|c|c|c|c|}
\hline & \multicolumn{2}{|c|}{ Basal/parabasal cells } & \multicolumn{2}{|c|}{ Median cell layer } & \multicolumn{2}{|c|}{ Surface cells } \\
\hline & p21 negative & p21 positive & p21 negative & p21 positive & p21 negative & p21 positive \\
\hline p53 negative & 0 & 0 & 0 & 0 & 0 & 0 \\
\hline p53 positive & 6 & 0 & 4 & 2 & 0 & 6 \\
\hline
\end{tabular}

control. The presence of human papillomavirus (HPV) infection was investigated using the NCL-PVp antibody (Novocastra), at a 1/100 dilution. This antibody detects all HPV types in paraffin wax embedded tissues. ${ }^{18}$ Positive controls were provided by a carcinoma in situ from the ectocervix. Strong nuclear and perinuclear staining was seen in most of the tumour cells. Furthermore, the expression of the $\mathrm{p} 53$ protein was studied using the antibody DO-7 (Dako, Hamburg, Germany), at a 1/50 dilution. Positive controls were carried out using a moderately differentiated gastric adenocarcinoma previously shown to be p53 positive. Intensive nuclear staining was found in more than $90 \%$ of cells on the invasion front. For all antibodies, negative controls were provided using normal horse serum with the same dilution.

EVALUATION OF STAINING RESULTS

Assessment of immunohistochemistry was done independent from classification of specimens. The following semiquantitative $\mathrm{p} 21^{\text {wafl/cip } 1}$ expression scores were used: negative staining, less than $5 \%$ positive nuclei, $5-15 \%$ positive nuclei, $16-25 \%$ positive nuclei, and more than $25 \%$ positive nuclei. Basal/parabasal cells, medial cell layers, and surface cells of the epithelium were evaluated. In nonpapillomatous nasal mucosa and cylindrical cell papillomas columnar epithelium were assessed. In inverted papillomas, columnar, transitional, and squamous epithelium were evaluated. In squamous cell carcinomas, representative regions on the invasion front of the tumour were investigated. Staining results were compared between these groups. In addition, $\mathrm{HPV}$ infection and $\mathrm{p} 53$ protein overexpression were studied and correlated with $\mathrm{p} 21^{\text {wafl/cip } 1}$ expression. Physiological expression of the p53 protein was defined as less than $15 \%$ immunoreactive basal/parabasal cells. Overexpression of the p53 protein was defined as positive

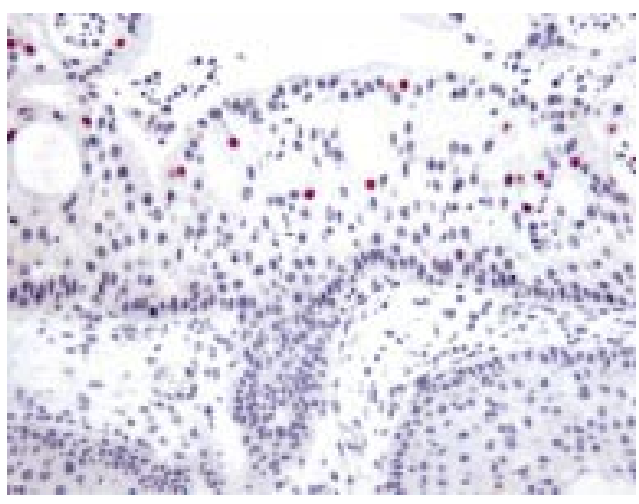

Figure 5 Cylindrical cell papilloma from a 54 year old man. Positive staining for $p 21^{\text {wafflicip } 1}$ is seen only in suprabasal and surface cells of the epithelium. staining of more than $15 \%$ basal/parabasal cells, and/or immunoreactivity more superficial than the parabasal cell layer. Furthermore, overexpression of the p53 protein was subgraded in cases showing more or less than $40 \%$ immunoreactive nuclei. ${ }^{19} 20$

\section{Results}

NON-PAPILLOMATOUS NASAL MUCOSA

All specimens were negative for $\mathrm{p} 21^{\text {wafl/cip1 }}$ staining. HPV infection and p53 protein overexpression were not found.

EXPRESSION OF $\mathrm{p} 21^{\mathrm{WAF} / \mathrm{CIP} 1}$ IN INVERTED PAPILLOMAS

p2 $1^{\text {waf1/cip1 }}$ was expressed in 16 of 20 cases (table 1). Immunoreactivity for $\mathrm{p} 21^{\text {waf1/cip1 }}$ was restricted to surface cells in five specimens (fig 1), but involved basal/parabasal cells in 11 specimens. Notably, in all cases immunoreactivity in basal/parabasal cells was separated from positive surface cells by negative medial cell layers of the epithelium. In some cases, positive staining in surface cells only along with positive staining in basal/parabasal cells only was detected in different regions within the same tissue section (fig 2). Frequently, the proportions of $\mathrm{p} 21^{\text {wafl/cipl }}$ positive basal/parabasal cells were enhanced in transitional and squamous epithelium compared with columnar epithelium. Positive staining for $\mathrm{p} 21^{\text {wafl/cip } 1}$ in basal/parabasal cells colocalised with p53 protein overexpression (figs 3 and 4). The expression of p53 protein predominantly involved basal/parabasal cells of the epithelium. In all inverted papillomas, less than $40 \%$ of the cells were immunoreactive for p53 protein.

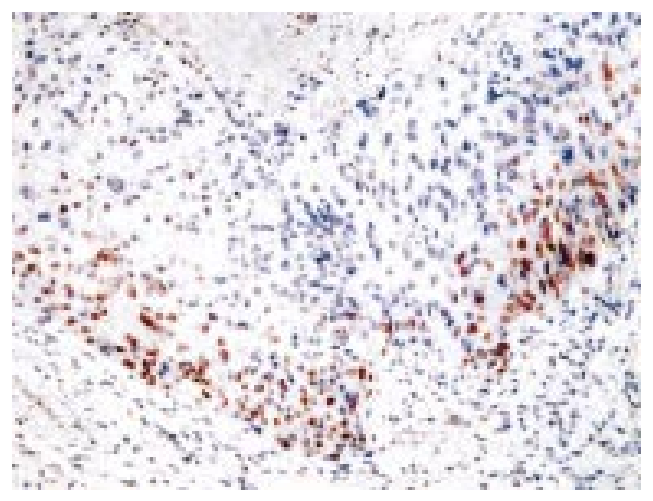

Figure 6 Squamous cell carcinoma associated with an inverted papilloma from a 61 year old man. Note immunoreactivity for $p 21^{\text {wafflcipip }}$ on the invasion front of the tumour. Necrotic areas of the tumour were negative for p2 $1^{\text {wafl Ilipit } 1}$ expression (upper part of the picture). Human papillomavirus infection was not detected in this specimen. Abundant overexpression of the $p 53$ protein was seen in this tumour. 
EXPRESSION OF $\mathrm{p} 21^{\mathrm{WAF} 1 / \mathrm{CP} 1}$ IN CYLINDRICAL CELL PAPILLOMAS

All specimens showed p2 $1^{\text {waf1/cip } 1}$ expression only in surface cells (table 2; fig 5). HPV infection and p53 protein overexpression were present in all cases.

EXPRESSION OF $\mathrm{p} 21^{\mathbb{W} A \mathrm{~F} 1 / \mathrm{CP} 1}$ IN SQUAMOUS CELL CARCINOMAS

One of five squamous cell carcinomas showed p2 $1^{\text {waf1/cip } 1}$ expression (fig 6). HPV infection was found in two cases and p53 protein overexpression was detected in all tumours.

\section{Discussion}

$\mathrm{p} 21^{\text {waf1/cip1 }}$ was not expressed in nonpapillomatous nasal mucosa. Currently, it is thought that tissue specific $\mathrm{p} 21^{\text {war1/cip } 1}$ expression occurs in terminally differentiated epithelial cells. $^{6}{ }^{2122}$ For instance, normal breast epithelium shows $\mathrm{p} 21^{\text {wafl/cip1 }}$ expression in less than $1 \%$ of cells. ${ }^{23}$ In contrast, normal colonic epithelium shows strong $\mathrm{p} 21^{\text {wafl/cip1 }}$ expression in the upper third of the crypts. ${ }^{24}$

We found $\mathrm{p} 21^{\text {waf1/cip } 1}$ expression in 16 of 20 inverted papillomas. Positive staining was seen in surface cells and basal/parabasal cells of the epithelium. Immunoreactivity for $\mathrm{p} 21^{\text {wafl/cip1 } 1}$ in surface cells was independent of p53 protein overexpression. Hence, p53 independent activation of $\mathrm{p} 21^{\text {wafl/cip } 1}$ expression along with terminal differentiation of surface cells in inverted papillomas can be postulated. A similar concept has recently been reported from oral squamous epithelium, in which p53 independent $\mathrm{p} 21^{\text {wafl/cip1 }}$ expression involves the spinous cell layer undergoing terminal differentiation. ${ }^{11125}$

The expression of $\mathrm{p} 21^{\text {wafl/cip1 }}$ in basal/ parabasal cells in inverted papillomas colocalised with p53 protein overexpression. At least two wild-type p53 protein responsive elements exist in the promoter region of the waf1/cip 1 gene. ${ }^{26}$ Expression of $\mathrm{p} 21^{\text {waf } 1 / \text { ip } 1}$ mediates the antiproliferative effect of $\mathrm{p} 53$ protein by the suppression of DNA replication and $G_{1}$ cell cycle arrest. ${ }^{3}{ }^{7}{ }^{26-28}$ Hence, it can be hypothesised that wild-type $\mathrm{p} 53$ dependent $\mathrm{p} 21^{\text {wafl/cip } 1}$ expression occurs in basal/parabasal cells in inverted papillomas. However, the antibody DO-7 used in our study recognises both wild-type and mutant p53 protein. ${ }^{29}$ The expression of p53 protein in less than $40 \%$ of cells was consistently found in our inverted papillomas. Recent studies have associated p53 protein expression in less than $40 \%$ of nuclei with the accumulation of wild-type rather than mutant p53 protein. ${ }^{30-32}$ Furthermore, a strong association between wild-type $\mathrm{p} 53$ protein and non-dysplastic inverted papillomas, in contrast to mutant p53 protein expression found in dysplastic specimens, has recently been reported. ${ }^{33}$ Dysplastic inverted papillomas were excluded from investigation in this study. Hence, it is probable that wild-type $\mathrm{p} 53$ protein was expressed in our exclusively non-dysplastic inverted papillomas, although further investigations involving molecular analysis of the p53 gene status are necessary to confirm these observations.
A causative role for HPV infection in the wild-type $\mathrm{p} 53$ protein overexpression seen in inverted papillomas is well recognised: complexing of the HPV oncoprotein E6 to wild-type $\mathrm{p} 53$ protein is followed by stabilisation and overexpression of the $\mathrm{p} 53$ protein in benign inverted papillomas infected with HPV types $6 / 11 . .^{34}{ }^{35}$ In contrast, degradation of these complexes followed by negative immunostaining for $\mathrm{p} 53$ protein is present in malignant sinonasal lesions infected with HPV types $16 / 18 .{ }^{35}{ }^{36}$ In agreement with previous reports, we found HPV infection in inverted papillomas but not non-papillomatous nasal mucosal specimens. ${ }^{35}{ }^{36}$ However, the individual HPV types were not subclassified in our study: the antibody NCL-PVp detects all human HPV types. ${ }^{18}$ Molecular techniques, such as the polymerase chain reaction, are required for reliable HPV subclassification. ${ }^{35} 37$ However, these techniques require fresh tissue ${ }^{35}{ }^{37}$ which was not available from the cases used in our study. Hence, further investigation will be necessary to clarify the relation between distinct HPV types and $\mathrm{p} 21^{\text {waf1/cip } 1}$ expression in inverted papillomas.

More $\mathrm{p} 21^{\text {waf } 1 / \mathrm{cip} 1}$ positive nuclei were found in transitional and squamous epithelium than in columnar epithelium in inverted papillomas. A consecutive series of histological changes has been demonstrated in inverted papillomas: columnar epithelium is gradually transformed to transitional epithelium and finally squamous epithelium. ${ }^{14} 38$ Our findings indicate increasing $\mathrm{p} 21^{\text {wafl/cip } 1}$ expression along this metaplastic process. We have recently identified increasing expression rates of $\mathrm{p} 53$ protein along this pathway, when investigating another cohort of inverted papillomas (manuscript in press). It is thought that $\mathrm{p} 21^{\text {wafl/cip } 1}$ plays a fundamental role in the suppression of papillomatous and metaplastic progression in epithelial tissues (such as the epidermis)..$^{39}$ Hence, p2 $1^{\text {wafl/cip } 1}$ may be involved in the regulation of metaplasia in inverted papillomas. Current studies suggest that $\mathrm{p} 21^{\text {wafl/cip } 1}$ has an inhibitory effect on viral DNA replication in HPV infected tissues, such as oral or genital papillomas. ${ }^{41}$ Further investigation is required to specify the detailed function of $\mathrm{p} 21^{\text {wafl/cip } 1}$ in inverted papillomas.

In cylindrical cell papillomas, $\mathrm{p} 21^{\text {wafl/cip } 1}$ expression was found only in surface cells of the epithelium. Thus, p21 $1^{\text {wafl/cip } 1}$ expression probably occurs along with terminal differentiation. HPV infection and p53 protein overexpression were present in all specimens. However, p $21^{\text {wafl/cip1 }}$ did not colocalise with p53 protein expression in basal/parabasal cells in cylindrical cell papillomas. Hence, activation of the waf1/cip 1 gene is probably p53 independent in this group of endophytic sinonasal papillomas. The different behaviour of inverted papillomas and cylindrical cell papillomas in p21 $1^{\text {wafl/cip1 }}$ expression cannot be explained from our data. A few previous studies have investigated cell cycle control in cylindrical cell papillomas, but none of those reports identified significant differences between inverted papillomas and cylindrical cell papillomas. ${ }^{37} 38$ Further investigations are needed to determine 
the basic mechanisms of cell cycle control in cylindrical cell papillomas.

In squamous cell carcinomas associated with endophytic sinonasal papillomas, p21 $1^{\text {wafl/cip1 }}$ expression was seen in one of five specimens, although $\mathrm{p} 53$ protein overexpression was found in all cases. Several concepts for heterogeneity in $\mathrm{p} 21^{\text {wafl/cip1 }}$ expression between individual tumours have recently been presented. ${ }^{42-45}$ For instance, mutant $\mathrm{p} 53$ protein is often unable to activate the transcription of the waf $1 /$ cip 1 gene in breast and gastric carcinomas with p53 gene

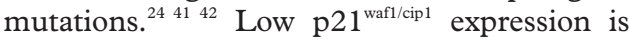
associated with poor prognosis in breast carcinomas. ${ }^{41}{ }^{42}$ Sinonasal carcinomas almost exclusively express mutant p53 protein, whereas wild-type p53 protein predominates in benign sinonasal lesions. ${ }^{33}$ Hence, the absence of $\mathrm{p} 21^{\text {wafl/cip1 }}$ expression in sinonasal carcinomas probably results from mutant p53 protein expression. However, in other neoplasms such as malignant melanomas or pancreatic carcinomas $\mathrm{p} 21^{\text {wafl/cip } 1}$ expression does not correlate with p53 functional status. ${ }^{44}{ }^{45}$ Transcription of the waf1/cip1 gene independent of p53 controlled pathways and post-transcriptional regulation of $\mathrm{p} 21^{\text {wafl/cip } 1}$ accumulation have been demonstrated in these lesions. ${ }^{4-47}$ Furthermore, recent studies have reported that cyclin D1 overexpression can regulate $\mathrm{p} 21^{\text {wafl/cip1 }}$ expression in several human malignancies, including head and neck squamous cell carcinomas. ${ }^{48}$ Hence, the exact regulatory mechanisms for $\mathrm{p} 21^{\text {wafl/cip } 1}$ expression in sinonasal squamous cell carcinomas cannot be determined from our data. Additional investigations involving p53 gene and protein alterations, wafl/cip 1 gene transcription, posttranscriptional p2 $1^{\text {waf1/cip1 }}$ modification, and cyclin D1 overexpression are necessary to shed light on $\mathrm{p} 21^{\text {wafl/cip } 1}$ expression and its prognostic value in sinonasal carcinomas.

1 Xiong Y, Hannon GJ, Zhang $\mathrm{H}$, et al. p21 is a universal inhibitor of cyclin kinases. Nature 1993;366:701-4.

2 El-Deiry WS, Tokino T, Velculescu VE, et al. WAF1, a potential mediator of p53 tumour suppression. Cell 1993;75:817-25.

3 El-Deiry WS. p21/p53, cellular growth control and genomic integrity. Curr Top Microbiol Immunol 1998;227:121-37.

$4 \mathrm{Li}$ Y, Jenkins CW, Nicols MA, et al. Cell cycle expression and $\mathrm{p} 53$ regulation of the cyclin-dependent kinase inhibitor p21. Oncogene $1994 ; 9 \cdot 2261-8$.

5 Waga S, Hannon GJ, Beach D, et al. The p21 inhibitor of cyclin-dependent kinases controls DNA replication by interaction with PCNA. Nature 1994;369:574-8.

6 Missero C, Calautti E, Eckner R, et al. Involvement of the cell-cycle inhibitor Cip1/WAF1 and the EIA-associated p300 protein in terminal differentiation. Proc Natl Acad Sci US A 1995;92:5451-5.

7 El-Deiry WS, Harper JW, O'Connor PM, et al. WAF1/CIP1 is induced in p53-mediated G1 arrest and apoptosis. Cancer Res 1994;54:1169-74.

8 Shiohara M, El-Deiry WS, Wada M, et al. Absence of WAF1 mutations in a variety of human malignancies. Blood 1994; 84:3781-4.

9 Bhatia K, Fan S, Sprangler G, et al. A mutant p21 cyclin-dependent kinase inhibitor isolated from Burkitt's lymphoma. Cancer Res 1995;55:1431-5.

10 Yook JI, Kim J. Expression of p21WAF1/CIP1 is unrelated to $\mathrm{p} 53$ tumour suppressor gene status in oral squamous cell carcinomas. Oral Oncol 1998;34:198-203.

$11 \mathrm{Ng}$ IOL, Lam KY, Ng M, et al. Expression of p21/waf1 in oral squamous cell carcinomas - correlation with p 53 and $\mathrm{mdm} 2$ and cellular proliferation index. Oral Oncol 1999;35. 63-9.

12 Shanmugaratnam K, Sobin LH. Histological typing of tumours of the upper respiratory tract and ear. Berlin: Springer, 1991 .

13 Bielamowicz S, Calacterra TC, Watson D, et al. Inverting papillomas of the head and neck: the UCLA update. Otolaryngol Head Neck Surg 1993;109:71-6.
14 Lawson W, Ho BT, Shaari CM, et al. Inverted papilloma: a report of 112 cases. Laryngoscope 1995;105:282-8.

15 Califano J, Koch W, Sidranski D, et al. Inverted sinonasal papilloma. A molecular genetic appraisal of its putative status as a precursor to squamous cell carcinoma. Am F Pathol 2000;156:333-7

16 Schwerer MJ, Kraft K, Baczako K. Structural changes in the gastric foveolar epithelium in Helicobacter pylori-positive gastritis revealed by keratin immunohistochemistry. Hum Pathol 1997;28:1260-7.

17 McKee PH, Hobbs C, Hall PA. Antigen retrieval by microwave irradiation lowers immunohistological detection thresholds. Histopathology 1993;23:337-79.

18 Shepherd PS, Lunny D, Brookes R, et al. The detection of human papillomaviruses in cervical biopsies by immunohistochemistry and in situ hybridization. Scand f Immunol 1992;36:69-74.

19 Cagle PT, Brown RW, Lebovitz ML. p53 immunostaining in the differentiation of reactive processes from malignancy in pleural biopsy specimens. Hum Pathol 1994;25:443-8.

20 Fang SY, Yan JJ, Ohyama M. Assessment of p53 protein expression in normal mucosa and benign and malignan lesions of the nasal cavity. Oncology 1998;55:168-73.

21 Steinman RA, Hoffman B, Iro A, et al. Induction of p21 (WAF1/CIP1) during differentiation. Oncogene 1994;9: 3389-96.

22 Parker SB, Eichele G, Zhang P, et al. P53-independent expression of $\mathrm{p} 21^{\mathrm{cip} 1}$ in muscle and other terminally differentiating cells. Science 1995;267:1024-7.

23 Barbareschi M, Caffo O, Doglioni C, et al. p21 waf1 immunohistochemical expression in breast carcinoma: correlations with clinicopathological data, oestrogen receptor status, MIB1 expression, p53 gene and protein alterations and relapse-free survival. Br f Cancer 1996;74:208-15.

24 Doglioni C, Pelosio P, Laurino L, et al. p21/WAF1/CIP1 expression in normal mucosa, adenomas and adenocarcinomas of the colon: its relationship with differentiation. $\mathcal{F}$ Pathol 1996;79:248-53.

25 Agarwal S, Mathur M, Shukla NK, et al. Expression of cyclin dependent kinase inhibitor $\mathrm{p} 21^{\text {wafl/cip1 }}$ in premalignant and malignant oral lesions: relationship with p53 status. Oral Oncol 1998;34:353-60. 26 El-Deiry WS, Tokino T, Waldman T, et al. Topological con-
trol of p21WAF1/CIP1 expression in normal and neoplastic tissues. Cancer Res 1995;55:2910-19.

27 Wu Y, Huang $\mathrm{H}$, Miner $\mathrm{Z}$, et al. Activities and response to DNA damage of latent and active sequence-specific DNA binding forms of mouse p53. Proc Natl Acad Sci USA 1997;94:8982-7.

28 Gervais JL, Seth P, Zhang H. Cleavage of CDK inhibitor p21 (Cip1/Waf1) by caspases is an early event during DNA damage-induced apoptosis. F Biol Chem 1998;273:1920712 .

29 Vojtesek B, Bartek J, Midgeley CA, et al. An immunohistochemical analysis of the human nuclear phosphoprotein p53. New monoclonal antibodies and epitope mapping using recombinant p53. F Immunol Methods 1992;151:23744

30 Rajendrakumar RI, Setzen G, Koltai PJ, et al. p53 protein expression in benign lesions of the upper respiratory tract. Arch Otolaryngol Head Neck Surg 1997;123:297-300.

31 Linden MD, Nathanson SD, Zarbo RJ. Evaluation of anti-p53 antibody staining: quality control and technical considerations. Appl Immunohistochem 1994;2:218-24.

32 Fouret P, Dabit D, Sibony M, et al. Expression of p53 protein related to the presence of human papillomavirus infection in precancer lesions of the larynx. Am $f$ Pathol 1995; 146:599-604.

33 Caruana SM, Zwiebel N, Cocker R, et al. p53 alteration and human papilloma virus infection in paranasal sinus cancer. haman papilloma virus inf

34 Franzmann MB, Buchwald C, Jacobsen GK, et al. Expression of p53 in normal nasal mucosa and in sinonasal papillomas with and without associated carcinoma and the relation to human papillomavirus (HPV). Cancer Lett 1998;128:161-4

35 Hwang CS, Yang HS, Hong MK. Detection of human papillomavirus (HPV) in sinonasal inverted papillomas using polymerase chain reaction (PCR). Am f Rhinol 1998;12: 363-6.

36 Zumbach K, Hoffmann M, Kahn T, et al. Antibodies against oncoproteins E6 and E7 of human papillomavirus types 16 and 18 in patients with head-and-neck squamous cell carcinoma. Int f Cancer 2000;85:815-18.

37 Mirza N, Montone K, Sato Y, et al. Identification of $\mathrm{p} 53$ and human papilloma virus in Schneiderian papillomas. Larynhuman papilloma virus in S

38 Michaels L, Young M. Histogenesis of papillomas of the nose and paranasal sinuses. Arch Pathol Lab Med 1995;119: 821-6.

39 Di Cunto F, Topley G, Calautti E, et al. Inhibitory function of p21Cip1/WAF1 in differentiation of primary mouse keratinocytes independent of cell cycle control. Science 1998;280:1069-72.

40 Weinberg WC, Fernandez-Salas E, Morgen DL, et al. Genetic deletion of $\mathrm{p} 21^{\mathrm{WAF} 1}$ enhances papilloma formation but not malignant conversion in experimental mouse skin carcinogenesis. Cancer Res 1999;59:2050-4.

41 Schmidt-Grimminger DC, Wu X, Jian Y, et al. Posttranscriptional induction of $\mathrm{p} 21 \mathrm{cip} 1$ protein in condylo-
mata and dysplasias is inversely related to human papillomavirus activities. Am f Pathol 1998;152:1015-24.

42 Carro D, Doglioni C, Veronese S, et al. Prognostic value of p2 $1^{\text {WAF1 }}$ and p53 expression in breast carcinoma: an 
immunohistochemical study in 261 patients with long-term follow-up Clin Cancer Res 1996;2:1591-9.

43 Johnson EA, Davidson AC, Hostetter RB, et al. The expression of Waf1 in node-negative infiltrating ductal breast carcinoma. Proceedings of the American Association for Cancer Research 1996;7:569.

44 Vidal MJ, Loganzo F, de Olivera AR, et al. Mutations and defective expression of the WAF1/p21 tumour-suppressor gene in malignant melanomas. Melanoma Res 1995;5:24350.

45 Digiuseppe JA, Redston MS, Yeo CJ, et al. p53-independent expression of the cyclin-dependent kinase inhibitor p21
46 Datto MB, Li Y, Panus JF, et al. Transforming growth factor $\beta$ induces cyclin-dependent kinase inhibitor p21 through p53-independent mechanism. Proc Natl Acad Sci U S A 1995;92:5545-9.

47 Upadhyay S, Li G, Liu H, et al. Bcl-2 suppresses expression of p21WAF1/CIP1 in breast cancer cells. Cancer Res 1995; 55:4520-4.

48 De Jong JS, van Diest PJ, Michalides RJ, et al. Concerted overexpression of the genes encoding $\mathrm{p} 21$ and cyclin D1 is associated with growth inhibition and differentiation in various carcinomas. f Clin Pathol: Mol Pathol 1999;52:7883.

\section{A demon in the bathroom}

Bathroom demons, an unusual theme for modern man, but in ancient Mesopotamia a daily hazard. Although certain aspects of ancient Mesopotamia, like the law code laid down by Hammurabi, have become ingrained in modern civilisation, others such as the colourful demonology have almost completely vanished in the limbos of time. Only certain members of the demonic family have in a way managed to survive. For instance, Incubus and its female counterpart Succubus have survived into modern psychiatry as the Incubus syndrome, in which there is the delusion of being sexually approached at night by an unseen lover. ${ }^{1}$

Other demons manifested themselves as diseases, the symptoms of which have in some cases been recorded in astonishing detail. Epilepsy, or disorders involving the patient turning "his neck to the left [ ...], while his hands and feet are stretched, his eyes are wide open, [ . . ] saliva flows in/from his mouth, he makes ... sounds; he does not know himself; [ . . . ] it overwhelms him time and again", ${ }^{2}$ could be caused by many different demons or deities, such as Antašubba, Bennu, or Lugal Urra. Another was Šulak, one of many names of the "Lurker" (Rābişu), a demon which "lies in wait for its victims in lonely places". ${ }^{2}$ In contrast to the other epilepsy or epilepsy-like inflicting demons, Sulak was an entity with a highly restricted territory, namely, the bathroom.

Demons lurking in bathrooms were also notorious among Jews, Arabs, and Europeans until the Middle Ages. ${ }^{2}$ In modern times, drowning in the bathtub of patients suffering from an epileptic insult is well known and described as a serious threat. ${ }^{3}$ Aside from epilepsy, cerebral haemorrhages ("if the right side of his body is in its entirety let down: stroke (inflicted by) a Lurker ..."2) may also frequently occur in the lavatory or bathroom, as recently pointed out in a Japanese study. ${ }^{4}$

Although ancient and modern aetiology may differ, it is interesting to see that the possible dangers surrounding a patient prone to epilepsy or strokes, while taking a bath, were already noticed over 2000 years ago.

F R W VAN DE GOOT

R L TEN BERGE

Department of Pathology, Vrije Universiteit Medical Centre, De Boelelaan 1117, 1081 HV Amsterdam, The Netherlands frw.goot@vumc.nl

1 Raschka LB. The incubus syndrome. A variant of erotomania. Can f Psychiatry 1979;24:549-53.

2 Stol M. Epilepsy in Babylonia. In: Geller MJ, Maul S, Wiggermann FAM, eds. Cuneiform monographs II. Groningen: Styx publications, 1993.

3 Ryan CA, Dowling G. Drowning deaths in people with epilepsy. Can Med Assoc f 1993;149:270.

4 Kamei I, Obayashi S, Nakagawa M, et al. When do strokes occur? Analysis of diurnal variation and activity during the onset [Japanese; English abstract]. No Shinkei Geka 1998;26:991-8. 